\title{
Comparison and enlightenment of optical higher education between America and China
}

Rui Wang, Xi Cheng Zhang, Lei Si

Rui Wang, Xi Cheng Zhang, Lei Si, "Comparison and enlightenment of optical higher education between America and China," Proc. SPIE 10452, 14th Conference on Education and Training in Optics and Photonics: ETOP 2017, 1045220 (16 August 2017); doi: 10.1117/12.2266485

SPIE Event: 14th Conference on Education and Training in Optics and Photonics, ETOP 2017, 2017, Hangzhou, China 


\title{
Comparison and Enlightenment of Optical Higher Education between America and China
}

\author{
Rui Wang*a Xi Cheng Zhang ${ }^{\mathrm{b}}$, Lei $\mathrm{Si}^{\mathrm{a}}$ \\ ${ }^{a}$ National University of Defense Technology, 47 Yan Wachi, Changsha, Hunan, China 410073; ${ }^{\text {b }}$ The \\ Institute of Optics, University of Rochester, 113 Wilmot Building, Rochester, NY USA 14627-0186
}

\begin{abstract}
In this paper, from the perspective of a teacher and a student, the differences on the educational implementation process, education effect, educational philosophy and thinking mode between America and China are studied, based on personal experience, visiting communication and research thinking etc.. The reasons for these differences are analyzed. The factors which influence a country's higher education, the core training contents and how to more effectively cultivate the talents of optics and photonics are also put forward. We hope this will help improve higher education.
\end{abstract}

Keywords: Higher education, difference between America and China, optics and photonics, educational philosophy

\section{INTRODUCTION}

In order to make the comparative study objectively reflect the main features and level of optical higher education in America and China, we have respectively chosen three universities which are well-known for optical education and research in America and in China. They are University of Rochester (UR) with The Institute of Optics, University of Arizona(UA) with College of Optical Sciences (OSC), University of Central Florida (UCF) with College of Optics and Photonics (CREOL), Zhejiang University with College of Optical Science and Engineering, Huazhong University of Science and Technology(HUST) with School of Optical and Electronic Information, National University of Defense Technology (NUDT) with College of Opto-Electronic Science and Engineering. Our in-depth understanding of SinoAmerican education is mainly from personal experience at NUDT and UR. The data is cited from the official website. Except for University of Arizona, the others were investigated by taking courses, lectures, workshops, TA, conferences, interviews etc..

Due to limited space, the differences on management mode, graduate program on admission, orientation and training mode will not be discussed in this article.

\section{COMPARISON ON OPTICAL HIGHER EDUCATION BETWEEN AMERICA AND CHINA}

There are no significant differences on school system, core curriculum setting and teaching form. Most notable differences are in the detail arrangement during the implementation process of teaching. Here we will specify it from the curriculum, course teaching, senior design, academic integrity education, teacher evaluation, campus environmental facilities.

\subsection{Curriculum}

The difference in curriculum design is mainly reflected in the following three points.

(1) Writing is classified as required course in America. Instead of Writing, Politics and English are listed as required courses in China.

(2) There are more experimental classes, more professional class hours, richer electives in America. The core optical courses at above three optical centers in America are equipped with corresponding lab courses ${ }^{[1-3]}$. For example, The Institute of Optics has set up four independent lab courses with a total of about 260 hours $^{[1]}$. NUDT has a comprehensive

14th Conference on Education and Training in Optics and Photonics: ETOP 2017, edited by Xu Liu,

Xi-Cheng Zhang, Proc. of SPIE Vol. 10452, 1045220 • () 2017 ICO, IEEE, OSA, SPIE

CCC code: $0277-786 X / 17 / \$ 18 \cdot$ doi: $10.1117 / 12.2266485$ 
opto-electronic lab course and two integrated design courses with less than 160 hours $^{[6]}$. UR has an optical professional course at the first year and Geometrical Optics at the first semester of the second year with more than 60 hours per course. NUDT has no optical professional courses at the first year and sets up Geometrical Optics with less than 60 hours at the second semester of the second year. The optics technical electives at The Institute of Optics are richer, up to $30^{[1]}$, which not only increased the breadth of the course content, but also improve the depth.

(3) The number of courses per semester taken by an undergraduate in China is about twice that of America ${ }^{[1-6]}$. For example, an undergraduate at UR takes about $4-5^{[1]}$ courses per semester, while at NUDT the number is about 7-10 (except for the senior year) ${ }^{[6]}$.

\subsection{Course teaching}

\subsubsection{Classroom teaching}

The outstanding features of classroom teaching at The Institute of Optics are as follows.

(1) The starting point is not high, but the content at the end of the course is deep. The teacher help students to develop basic and important ability step by step. For example, in lab class, students learn how to write science \& technology experimental report. In China, in most cases, students get the template, but don't be taught how to write a report.

(2) It is normal to solve problems with professional softwares. For example, students learn Matlab for programming, Code V for lens design in class. China has also used software in course teaching, such as Zemax for lens design, but not yet formed a general, conventional software teaching awareness in undergraduate stage.

(3) The knowledge are closely connected to practical application. For example, Math Methods for Optics and Physics is not just a math course. Many examples of optical applications are given, which help students connect mathematics knowledge with how to use them to solve optics problem. Mathematics curriculum in China has weaker connection with professional practice.

(4) Scientific \& technological writing ability and oral expression ability are attached great importance to. Oral presentation and poster are widely used as teaching methods. Lab report commonly uses figures and tables to illustrate problems. China has not intentionally arranged these special training during undergraduate stage.

\subsubsection{Classroom behavior requirements for students}

In American class, being late, leaving early, eating food, even putting legs on the table are allowed, which are scarce or not allowed in Chinese class. Students can ask teacher questions at any time in class. On the contrary, in Chinese class, students are generally asked by teacher.

\subsubsection{Textbook}

In America, most courses have no textbook. Students learn from the teacher's notes, slides and a bunch of bibliography. In China, most courses have textbooks. Teacher teaches by the order of textbook's chapters. The construction of excellent textbooks is attached great importance to.

\subsubsection{Homework}

In America, most homeworks are more difficult than class contents, and some teachers also specifically arrange selfstudy content in the homework. Students need to search and read literatures, discuss before completing assignments.

In China, most homeworks are not very difficult and generally can be finished by carefully reading textbooks. On the other hand, if homework is so difficult that students have to spend more time in finishing them, a large number of required courses also make students no enough time and energy to complete them.

\subsubsection{Counseling}

The counseling ways at The Institute of Optics mainly include weekly workshop, Q \& A open time of TA and teacher per week, and e-mail. In addition, discussion among students is an universal learning approach.

In China, the counseling ways mainly include homework commentary in class, Wechat out of class and Q \& A class before test. 


\subsubsection{Examination}

In America, evaluation of students has three prominent features:

(1) Each assignment and exam are weighted to the final score and the weight of final exam will not exceed $50 \%$.

(2) There are 1 or 2 mid-term examinations except the final exam.

(3) There are more oral presentations and posters, which are similar to international conference and are used to assess students.

In China, theory courses for undergraduates usually have only one final exam that accounts for decisive proportion of final score, and is mainly written test.

\subsection{Senior Design}

At The Institute of Optics, senior design is a course headed by an instructor (professor). Topics of senior design are divided into Optics and Optical Engineering. Optics design come from professors, which need to be independently completed by one student. Optical Engineering design, which need to be completed by 3-4 students together, mostly come from optical companies. The vast majority of students are willing to choose the latter. At fall semester of senior year, companies will present their requirements to attract students to undertake their projects. After selecting a project, students need to communicate with the company, negotiate technical indicators, determine work plan and task division, all of which must be completed before the fall semester. From the spring semester, students begin to do the project, further communicate with the company. The instructor guides students during this period. Student's academic performance is evaluated by company and instructor based on satisfaction of project. Students doing well may gain an opportunity of internship or even a job. Students who don't pass it will not be able to earn credits, need to retake or apply for other professional degrees.

In China, topics of senior design mostly come from teachers' research projects. At fall semester of senior year, a student select one subject from a large number of topics according to the text outline provided by teachers, instead of oral presentation. Each student need to independently complete the task, usually guided by a teacher and a graduate.

\subsection{Academic integrity education}

UR sends materials of academic integrity to freshmen. Most teachers will point out detailed academic integrity requirements in the first class and follow them. In China, academic integrity education mainly comes from instructor and regulation, lacks a special training.

\subsection{Teacher evaluation}

In America, teachers are evaluated by students through Teacher Evaluation System. Students can timely see the scores only after evaluation. Evaluation results can be inquired and comments will be directly sent to the teacher. The Institute of Optics also has teaching feedback meeting, at which students can reflect on teaching issues.

In China, teachers are evaluated by students and experts. Supervision experts grade teachers by randomly attending classes.

\subsection{Campus environmental facilities}

Walking in campus or into office buildings at an American university, you will find, many tables and chairs in public area, conference rooms with blackboard, classrooms are in the same building with teachers' offices. Each teacher has a single office room although not big.

At a Chinese university, there are less tables and chairs in public area. Conference rooms are equipped with projector, but blackboard is not common. There are special Teaching Buildings which are generally far from teachers' office building. Except leader and senior professor, usually several teachers share a big office room. 


\section{DIFFERENT WAY OF THINKING}

Above surface differences reflect different way of thinking between America and China, which evolved from different historical experiences.

\subsection{Comparison of the way of thinking between America and China}

Through long-term observation and in-depth thinking, in Table 1, we list different habits of thinking in some typical aspects such as learning, work, evaluation, management etc. between America and China. Table 2 lists connection between the way of thinking and teaching process design in America. Table 3 lists that in China.

Table 1. Different habits of thinking between America and China

\begin{tabular}{|l|l|l|}
\hline \multicolumn{1}{|c|}{ Item } & \multicolumn{1}{c|}{ America } & \multicolumn{1}{c|}{ China } \\
\hline Learning habit & Learn in the process of solving problem. & $\begin{array}{l}\text { First learn knowledge and skill, and then } \\
\text { solve the problem (in the subconscious). }\end{array}$ \\
\hline Work habit & Scientific research type. Practical type. & Humanistic type. Theoretical type. \\
\hline Evaluation habit & $\begin{array}{l}\text { Pay attention to process evaluation for student } \\
\text { and result evaluation for teacher. }\end{array}$ & $\begin{array}{l}\text { Pay attention to result evaluation for student } \\
\text { and process evaluation for teacher. }\end{array}$ \\
\hline Management habit & Service. & Manage \& control. \\
\hline $\begin{array}{l}\text { Political and } \\
\text { cultural atmosphere }\end{array}$ & $\begin{array}{l}\text { Pursue freedom. Respect privacy. Critical. } \\
\text { From down to top. Carry forward the strengths }\end{array}$ & $\begin{array}{l}\text { Authority and obey. From top to down. } \\
\text { Improve the weakness. }\end{array}$ \\
\hline $\begin{array}{l}\text { Educational } \\
\text { characteristics }\end{array}$ & $\begin{array}{l}\text { Focus on solving problem. Like practice. Good } \\
\text { at hands. Better meet cognitive laws. }\end{array}$ & $\begin{array}{l}\text { Focus on learning knowledge and skills, and } \\
\text { organization of knowledge. Some do not meet } \\
\text { cognitive laws. }\end{array}$ \\
\hline
\end{tabular}

Table 2. Connection between the way of thinking and teaching process design in America

\begin{tabular}{|l|l|l|}
\hline The way of thinking & \multicolumn{1}{|c|}{ Teaching Process Design } & \multicolumn{1}{c|}{ Teaching effect } \\
\hline \multirow{4}{*}{$\begin{array}{l}\text { Learn in the process of } \\
\text { solving problem }\end{array}$} & $\begin{array}{l}\text { No textbook for most courses. Homework is } \\
\text { relatively more difficult than class contents. }\end{array}$ & $\begin{array}{l}\text { Active learning. Get knowledge } \\
\text { points and lack organization of } \\
\text { knowledge. } \\
\text { In fact, people learn in this way in } \\
\text { their real work. }\end{array}$ \\
\cline { 2 - 3 } & Less number of courses per semester & $\begin{array}{l}\text { Meet cognitive law. } \\
\text { More self-digestion time. }\end{array}$ \\
\cline { 2 - 3 } & $\begin{array}{l}\text { Training writing and oral expression ability in } \\
\text { the process of long-term use (such as lab report) }\end{array}$ & $\begin{array}{l}\text { Meet cognitive law. } \\
\text { Helpful to truly master this ability. }\end{array}$ \\
\hline \multirow{2}{*}{$\begin{array}{l}\text { Pay attention to } \\
\text { process evaluation for } \\
\text { student }\end{array}$} & $\begin{array}{l}\text { Each exam and homework is weighted to the } \\
\text { final scores. }\end{array}$ & $\begin{array}{l}\text { Students can't neglect each } \\
\text { homework and exam. Help supervise } \\
\text { students to review timely, sort out the } \\
\text { contents of study, keep up with the } \\
\text { progress of learning, avoid pre-test } \\
\text { short time review. At the same time } \\
\text { teachers can also get feedback on } \\
\text { learning effect of students. }\end{array}$ \\
\hline $\begin{array}{l}\text { Pay attention to result } \\
\text { evaluation for teacher }\end{array}$ & Base on final students' evaluation & $\begin{array}{l}\text { Partly influence teacher's prestige and } \\
\text { student source. Respect personality } \\
\text { and privacy. }\end{array}$ \\
\hline \multirow{2}{*}{ Scientific research type } & $\begin{array}{l}\text { Need to search and read literature, discuss in } \\
\text { order to finish homework }\end{array}$ & $\begin{array}{l}\text { Learning process focuses on solving } \\
\text { problem. }\end{array}$ \\
\cline { 2 - 3 } & $\begin{array}{l}\text { Special training of writing and oral expression } \\
\text { ability (more presentation and poster) }\end{array}$ & $\begin{array}{l}\text { Students are able to acquire the } \\
\text { practical abilities needed to survive in }\end{array}$ \\
\hline
\end{tabular}




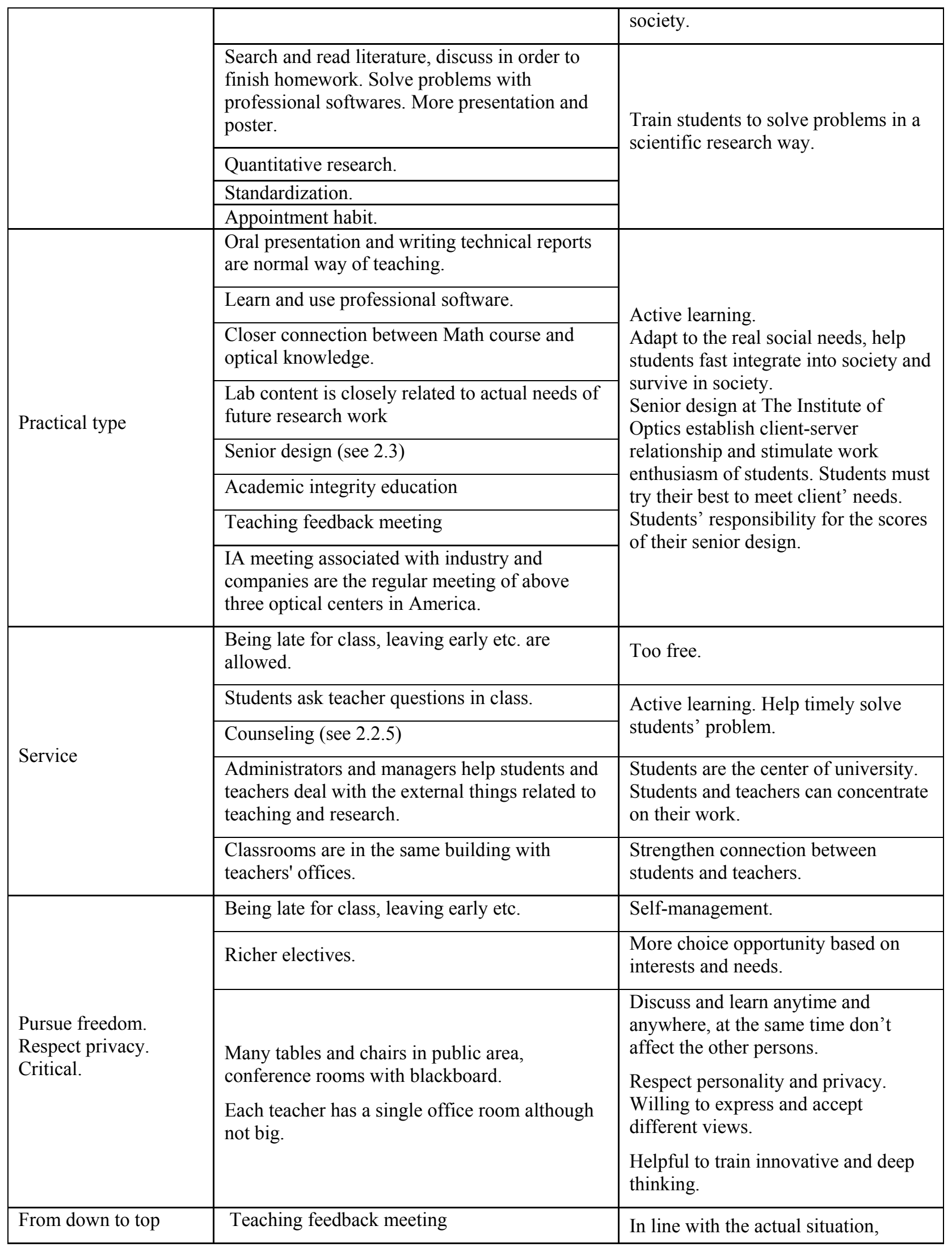




\begin{tabular}{|l|l|l|}
\hline & & improvement is effective. \\
\hline $\begin{array}{l}\text { Carry forward the } \\
\text { strengths }\end{array}$ & $\begin{array}{l}\text { Find and encourage everyone's strengths. Don't } \\
\text { force everyone to be good at all aspects. More } \\
\text { encourage than criticism. }\end{array}$ & Students are more confident. \\
\hline
\end{tabular}

Table 3. Connection between the way of thinking and teaching process design in China

\begin{tabular}{|c|c|c|}
\hline The way of thinkin $\$$ & Teaching Process Design & Teaching effect \\
\hline \multirow{3}{*}{$\begin{array}{l}\text { First learn knowledge } \\
\text { and skill, and then solve } \\
\text { the problem (in the } \\
\text { subconscious) }\end{array}$} & The way of learning English and Politics & \multirow{3}{*}{$\begin{array}{l}\text { Passive learning. Weaker connection } \\
\text { with practical application. Weaken the } \\
\text { ability to solve practical problems. } \\
\text { Limit the way of solving problem and } \\
\text { innovative thinking. }\end{array}$} \\
\hline & $\begin{array}{l}\text { Teach more knowledge and skills, No } \\
\text { difficult enough homework. }\end{array}$ & \\
\hline & More required courses than America. & \\
\hline $\begin{array}{l}\text { Pay attention to result } \\
\text { evaluation for student }\end{array}$ & $\begin{array}{l}\text { Final exam accounts for decisive proportion } \\
\text { of final score. }\end{array}$ & $\begin{array}{l}\text { Easy to make students get high marks } \\
\text { by pre-test short time review. } \\
\text { Not conducive to the grasp of } \\
\text { knowledge. }\end{array}$ \\
\hline $\begin{array}{l}\text { Pay attention to process } \\
\text { evaluation for teacher }\end{array}$ & $\begin{array}{l}\text { Supervision experts grade the teachers by } \\
\text { randomly attending classes. }\end{array}$ & $\begin{array}{l}\text { Make teachers pay more attention to } \\
\text { teaching work and help young teachers } \\
\text { grow up quickly. }\end{array}$ \\
\hline Humanistic type & $\begin{array}{l}\text { Lay great emphasis on humanistic factors } \\
\text { during doing things. }\end{array}$ & $\begin{array}{l}\text { Affect the efficiency and effectiveness } \\
\text { of doing things. } \\
\text { The way of thinking has qualitative } \\
\text { bias, lacks quantitative analysis. }\end{array}$ \\
\hline \multirow{6}{*}{ Theoretical type } & $\begin{array}{l}\text { Teach by textbook. Focus on teaching the } \\
\text { theory. Lack connection with the actuality }\end{array}$ & \multirow{6}{*}{$\begin{array}{l}\text { Better abstract thinking, better } \\
\text { mathematical basis, better organization } \\
\text { of knowledge. } \\
\text { Inadequate training in the ability to } \\
\text { survive in society. }\end{array}$} \\
\hline & Lack practical writing courses & \\
\hline & Less oral expression opportunities & \\
\hline & $\begin{array}{l}\text { No enough close connection between Math } \\
\text { courses and optical profession }\end{array}$ & \\
\hline & $\begin{array}{l}\text { Lack special academic integrity education in } \\
\text { the undergraduate stage. }\end{array}$ & \\
\hline & $\begin{array}{l}\text { The teaching content isn't closely related to } \\
\text { the actual needs of future work. }\end{array}$ & \\
\hline \multirow{4}{*}{$\begin{array}{l}\text { Manage \& control. } \\
\text { Authority and obey. }\end{array}$} & $\begin{array}{l}\text { Students are asked questions by teacher in } \\
\text { class. }\end{array}$ & \multirow{2}{*}{$\begin{array}{l}\text { Passive learning. Chinese students } \\
\text { relatively lack the spirit to question and } \\
\text { resist the authority. }\end{array}$} \\
\hline & Tutorial classes on fixed time & \\
\hline & $\begin{array}{l}\text { Being late, leaving early, eating food, even } \\
\text { putting legs on the table are scarce or not } \\
\text { allowed. }\end{array}$ & Respect the teacher and the authority. \\
\hline & Senior design (see 2.3) & $\begin{array}{l}\text { Generally establish teacher-student } \\
\text { relationship, teachers will try their best }\end{array}$ \\
\hline
\end{tabular}




\begin{tabular}{|l|l|l|}
\hline & & $\begin{array}{l}\text { to help guide students complete the } \\
\text { subject and pass the defense. } \\
\text { Responsibility of teacher and student } \\
\text { for the scores of senior design. } \\
\text { The excitation of study enthusiasm is } \\
\text { not enough. }\end{array}$ \\
\hline From top to down & Directly release reform views & $\begin{array}{l}\text { Easy to conflict with the actual } \\
\text { situation, improvement is limited. }\end{array}$ \\
\hline Improve the weakness & $\begin{array}{l}\text { Teachers and parents tend to focus on } \\
\text { finding and pointing out the lack of students. } \\
\text { Hope everyone to be good at all aspects. } \\
\text { More criticism than encourage. }\end{array}$ & $\begin{array}{l}\text { Students are easy to be cautious. } \\
\text { Unwilling to express and discuss. } \\
\text { Maybe relatively lack confidence. }\end{array}$ \\
\hline
\end{tabular}

Regardless of complicated political reasons behind historical events, those historical experiences have naturally shaped people's personality and way of thinking, which further created excellent achievements in certain areas such as American science and technology, Chinese philosophy.

\subsection{Historical reasons for American way of thinking}

3.2.1 People with the spirit of rebellion, pioneer and adventure gathered together and formed a cultural atmosphere pursuing freedom, democracy, personality, adventure and innovation.

You can imagine, only such a group of people who have pioneer and adventure spirit may choose to come to this strange land to look for a new life. For example, the pilgrims on the MayFlower who fought against the Anglican Church are such a group of people who have rebellion spirit, courage to pursue freedom, dreams and happiness. At the same time they are so wise to formulate the "MayFlower Convention". In addition, among these people there are leaders such as George Washington etc. Just such a group of people came together and may form a cultural atmosphere with freedom, democracy, personality, adventure and innovation. The success of the Independent War, the Civil War, Westward Movement indicates such national characters. The above characters made America form the academic atmosphere with "dare to think, dare to do, dare to say, pay attention to personal inner demand, dare to question, willing to comment and discuss".

\subsubsection{The early harsh living conditions had shaped American pragmatic craftsman spirit, habit of learning in} practice and specific linguistic feature.

The early immigrants suffered from hunger and the Indian on an unfamiliar land, plus a century of Westward Movement. In the face of harsh living conditions, they must think, act, learn how to survive from generation to generation. For example, in the process of developing the West, they must solve practical problems in front of them one by one, which gradually shaped American style of doing things with pragmatic spirit and learning in practice, and American education characteristics with "regard solving problem as core orientation, like hands-on practice, clear and specific education goal, achieve dreams by personal struggle".

\subsubsection{High-quality immigrants and rapid development of industrialization promote America to form advanced} scientific methods of doing things.

America was established during the period of modern civilization. The British who came to the new continent have experienced the first industrial revolution in which their scientific consciousness and ability had had a certain development. In this new and no historical bondage/burden country, technology have objective conditions to be rapidly developed so that the second industrial revolution marked by electrification quietly occurred in America. A longer period of industrialization process and achievements stimulated scientific thinking mind of courageous and knowledgeable smart people, and provided them with opportunities to establish and rapidly develop scientific and efficient work methods such as how to optimize production process, how to efficiently manage, how to protect intellectual property rights etc.. "Scientific research" style of doing things gradually was built up. This style has gradually penetrated into higher education, such as learning habit of research and discuss, use of professional software, establishment of various standards, quantitative research methods, teaching methods associated with practical application, rigorous and pragmatic attitude. These are worthy of study. 


\subsection{Historical reasons for Chinese way of thinking}

\subsubsection{Early reaching the peak of human thoughts has prompted China to form education method of preaching}

and abstract linguistic feature.

Confucianism, most important part of Chinese traditional ideology and culture especially in education, originated from the Spring and Autumn Period around 500 BC, which had been also praised by the rulers of Chinese feudal society for more than 2000 years. Many questions about life, morality, society, politics and economy can be explained by mature ideas which are also respected by the society for a long time. In such a social environment, it is easy to form thought authority and hard to generate innovative ideas. The power, the elder and the teacher are authority with attitude of preaching to enlighten others. Long-term authority make Chinese students relatively lack the spirit to question and resist authority.

In addition, long-term highly abstract way of thinking make Chinese be used to say all-encompassing truth for the universe. Chinese language emphasizes thoughtfulness and comprehensiveness, so people without relevant practical experience (especially young people) often feel not it's subtle but "big and empty", and difficult to find the starting point of practice. On the contrary, American language emphasizes specificity, which makes people easy to understand and operate. Expression differences in training goal also show above linguistic features.

3.3.2 Long-term Confucianism education formed Chinese characteristics of obeisance, introspection and modesty.

Impacted by "the power, the elder, and the teacher are authority", Chinese formed obeisance instead of argument mentality in front of authority. Chinese are accustomed to finding faults to help improve, which leads people tend to think carefully before saying in order to avoid too much criticism. Especially in a foreign country whose native language hasn't been mastered, Chinese students have less initiative to express their views in class, obviously different from American students. In addition, Chinese emphasize modesty, which means "don't be proud". So Chinese don't tend to praise themselves, maybe many foreigners do not understand it.

\subsubsection{International exchange and social change in China have prompted Chinese to awake and reflect.}

More and more Chinese, especially high-caliber talents, are studying, travelling, working or living abroad. These people could feel different lives in other countries, which will stimulate them to reflect on their own state of life and work, further analyze which is better, why to live and work in such a way, what we learn from etc., and gradually form objective and critical cognition, rather than blind obedience. Different views continue to emerge, forming a benign, innovative, democratic cultural ecology.

Science, technology and economy are rapidly developing in China. New problems will inevitably appear with developments, and also stimulate people to think about a new way of life and work as what had happened in America. The situation calls for new educational philosophy that better accords with cognitive laws and social needs.

\subsubsection{A large population and highly competitive pressure make Chinese more striving.}

By 2016, China has a population of about 1.4 billion, four times more than America. In such an environment, Chinese children have to work harder, and Chinese parents have to pay more attention to education in order to get better opportunities to survive and develop.

\section{ENLIGHTENMENT}

\subsection{The influence factors in training program, mode and development of a country's higher education}

\subsubsection{Social needs}

Service object of higher education is person, who eventually has to enter the society in order to get better opportunities for survival and development. Education, especially university education, is far from a relationship between teacher and student, but relationship between person and society. The university should cultivate talents which the society needs. Different times require different training contents and patterns. Even at the same era, demands for talents in different countries are also different. For example, in post-war recovery period, economic development period, or innovation period, cultivation mode should be different. A country should select training program and mode which can fill its own 
social needs, can't directly copy from other country. Cooperation between different countries or training institutions is an important way to cultivate different levels of talents.

\subsubsection{National history and social culture}

National history had been shaping a country's unique cultural atmosphere, people's typical characters and the way of thinking, which affect a country's education mode in the subconscious. Exchanges between countries with different cultural and historical backgrounds help understand each other's strengths and weaknesses, and promote common progress. Educational cooperation between universities in different countries is an important way to communicate.

\subsubsection{Teacher-student ratio}

Generally, American universities have higher teacher-student ratio, so small class teaching and research type of education are logical. The number of students in China may be unimaginable for American, which raises a series of issues: how to ensure attention to every student, how to build a laboratory, how many equipment to purchase, etc.. How to provide high-quality education in the case of small teacher-student ratio is an important problem which China needs to innovatively solve.

\subsubsection{Education mode before university education}

American high schools have taken a similar mode to university education, such as credit system, group study, electives, oral presentation etc. So students from American high school are easy to adapt to university learning life. China takes exam-oriented education before higher education. If university education in China take American mode, students need longer time to adapt to the new learning way.

\subsection{What kind of education should university provide?}

\subsubsection{The soul of education is to help students self-discover or find what inspire their passion for life.}

While reflecting on the meaning of life, observing different students and the life state of successful people, you will find people are easier to gain achievements and happiness when working with the interest, and feel the value of life. Perhaps this is the significance of life. Universities have conditions and responsibilities to help students find what inspire their passion for life.

Compared to other stages of education, university education provides students with a better platform to find what can motivate them. The main reasons are as follows. First, students come from different places. The blend of different cultures will broaden students' horizons. Second, there are more opportunities to learn different courses. Third, there are more extra-curricular activities and academic communication platforms to help students find their own interests. Fourth, there is teachers' guidance. How to find it? There are two ways which are self-discovery and teacher-discovery. Students can discover their interests through university platforms by themselves, which is the most feasible way. Teachers can help students find their interests in the process of communication, which is one of important education responsibilities of teacher, but often not realized or taken seriously enough.

4.2.2 The goal of higher education, with knowledge and skills as a carrier, is to train intrinsic quality, depth, breadth and way of thinking.

The essential difference between human and other animals, between different persons, is thinking of brain. The essence of education is to develop people's thoughts and train their minds.

What are the determinants of success? Knowledge and skills? Maybe. But a lot of people with knowledge lack success, some successful people haven't mastered a body of knowledge. The way of thinking and excellent intrinsic qualities, such as enthusiasm for work and life, concentration, diligence, responsibility, justice, integrity, execution, perseverance, courage and determination to overcome difficulties, self-management ability, innovative thinking, etc., have determined the success of a person. Knowledge and skills can be transformed into problem-solving ability only by the way of thinking and intrinsic quality.

Additionally, brain is amazing, through a particular medium to improve thinking ability, you can synchronize to improve the level of doing other things. In the process of imparting knowledge and skills, teaching in the right way can also improve students' thinking abilities and intrinsic qualities. With this philosophy, teacher can come up with a lot of teaching methods. How to lecture, how to assign homework, and how to set up lab course etc. are about to change. 
Through university education, we hope that students will be competent for different types of jobs (even different profession) by learning new knowledge and skills.

At present, undergraduate education in China and America mainly trains students' breadth of thinking, such as the input of a lot of knowledge and skills, not realizing or paying more attention to the training of depth and way of thinking. Critical thinking is only one of the ways of thinking. In depth thinking training, America does better, for example, more difficult homework, more discussion, and more practice.

\subsubsection{The spirit and methods of scientific research should be important part of undergraduate education.}

Here the spirit of scientific research contains two meanings. First, when facing a problem, a person gets a solution by investigation and study, rather than subjective imagination. Second, for a work, a person does well through research. The methods of scientific research refers to mature and efficient methods used in the process of scientific research such as information retrieval, statistical analysis, modeling and simulation etc.. If the spirit and methods of scientific research are applied to daily life and work, all walks of life will flourish. So the spirit and methods of scientific research should be important part of undergraduate education, not until the PH. D.. Of course, the sooner is the better.

\subsection{The implementation of higher education must conform to the cognitive laws}

\subsubsection{Training program design should balance the conversion rate and the input of $K$. S..}

K. and S. refer to knowledge and skills respectively. The conversion rate of K. S. can be expressed as below.

$$
\text { The conversion rate of K. S. }=\frac{\text { The output of K. S. }}{\text { The input of K. S. }}
$$

The output of K.S. means all the knowledge and skills that can be used to think and solve problems by a person. Teaching effect should be measured by the conversion rate of K. S., not the input of K.S.. Higher education in China over-emphasizes on the input and ignores the output of K.S. without paying more attention to restrictions of students' physiology and self-digestion time etc. on the conversion rate. This is manifested in supersaturation of the number of courses and curriculum content, and less self-digestion time.

To slim core curriculum, enrich electives and improve the quality of courses is an important way of curriculum reform in Chinese universities. American universities may strengthen the organization of knowledge and training of depth thinking.

\subsubsection{Innovation is a product of interest, long-term practice and reflection.}

Everyone's time and energy are limited. Only through self-thinking and practice can people master knowledge and skills, acquire thinking ability and intrinsic qualities. Only by doing what interests, practice and thinking over a long period of time can we generate innovation. Above objective laws are design principles that education management needs to follow.

Arousing students' interest in learning, and cultivating students' habit of being diligent in practice and thinking is the key to training creative ability. Deeply involved in lab courses and course projects is an important way to cultivate innovative talents.

\subsection{How to more effectively cultivate the talents of optics and photonics?}

Optics is an ancient and young subject, closely related to people's production and life. The introduction and integration of achievements of other disciplines and new technologies have expanded the field of Optics and deepened the understanding of light. At present, many aspects of Optics and Photonics are involved in many frontiers of science. They provide rich materials and various ways for training students' innovative thinking and excellent internal qualities.

In classroom teaching, we should not only teach knowledge, but also talk about the history of knowledge formation in order to learn how to think from previous scientists. This is an important way to train thinking mode. Introducing interdisciplinary and cutting-edge knowledge help students broaden breadth of thinking, enable students to feel the limitations and transplantation of knowledge, learn the methods of scientific research. The practical problems can be introduced into the course teaching as course projects, especially senior design. Solving the practical problems can stimulate students' interest of learning. In the process of solving project problems, by overcoming difficulties, the integrated using comprehensive knowledge, collective discussion and team cooperation etc., students will train the depth of thinking, learn scientific research methods and form good inner qualities. 
In experimental teaching, when students encounter problems and difficulties, teachers should guide and inspire them to come up with solutions by themselves instead of giving answer directly. By increasing lab opening hours, we can increase the time of self-exploration, self-reflection and collective discussion in experiments, enhance the depth of thinking and stimulate innovative ideas.

\section{REFERENCES}

[1] The Institute of Optics, UR, “Undergraduate-Handbook," August 2016, http://www.optics.rochester.edu/assets/pdf/Undergraduate-Handbook.pdf

[2] College of Optical Science, UA, "Undergraduates Program," 2017, http://www.optics.arizona.edu/academics/bs-in-ose/requirements

[3] College of Optics \&Photonics, UCF, "Undergraduates Program,” 2017, http://www.creol.ucf.edu/Academics/Undergrad/Courses.aspx

[4] School of Optical and Electronic Information, HUST, "Undergraduates Program", 2015, http://oei.hust.edu.cn/Undergraduate/4/index_1.htm

[5] College of Optical Science and Engineering, Zhejiang University, "Undergraduates Program”, 2017, http://opt.zju.edu.cn/opt-edu/redir.php?catalog_id=3738

[6] Training department, National University of Defense Technology, [Undergraduates Program], National University of Defense Technology Publisher, Changsha, (2012).

\section{ACKNOWLEDGEMENT}

I gratefully acknowledge NUDT and UR that provide me with an opportunity to visit America. Special thanks to my two supervisors, Prof. Xicheng Zhang and Prof. Carlos R. Jr. Stroud at UR, I couldn't finish this meaningful research work without their help, support and guidance. Many thanks to Professor Shiqiao Qin, Dr. Hairong Zhong and Yongzhong Chen at NUDT for the support of this research work. Many thanks to Prof. Bahaa E. A. Saleh, Prof. David J. Hagan and Prof. Guifang Li for providing me with an opportunity to visit CREOL. Thanks to Prof. Miguel A. Alonso, Prof. Andrew J. Berger, Prof. Julie Bentley, Prof. Svetlana G. Lukishova, Prof. James R. Fienup, Prof. Jannick Rolland at UR; Prof. Shin-Tson Wu, Prof. Zenghu Chang, Prof. Michael Bass, Prof. M.J. Soileau, Prof. Eric W. Van Stryland, Prof. M. G. "Jim" Moharam, Prof. Shuo "Sean" Pang, Prof. Weili Luo at UCF; Prof. Xu Liu, Prof. Zhenrong Zheng, Prof. Yuanfang Lin, Prof. Cuifang Kuang, Dr. Xiaojie Zhang at Zhejiang University; Prof. Xinliang Zhang, Prof. Ying Wang at HUST; Prof. Chanlao Liu, Prof. Junqi Xu, Prof. Hongli Yang at Xi'an Technological University. Also thanks to all the teachers, students and friends who helped and supported me in my research, here are not listed one by one. 